\title{
Qualitative Transformation National Banking System
}

\author{
Kropin Yuri Anatolyevich \\ Department of financial markets and banks of SEI HE "Financial University under the Government \\ of the Russian Federation", Financial University,Moscow, Russia
}

Keywords: Monetary System of The Country; National Banking System; Central Bank; Commercial Banks; Russian School of Economic Thought.

Abstract: The subject of the research is the qualitative transformation of the national banking system, the beginning of which can be a revelation of its real nature in modern conditions. The purpose of the article is to reveal the view of the Russian school of economic thought on the essence of the banking system, which is positioned by it not as a branch of the national economy, but as an integral part of the country's monetary system. In this regard, the article argues that the purpose of the functioning of the banking system in modern conditions should be not getting its own profit, but providing conditions for creating a national gross income. The peculiarity of the article's methodology is that the nature of the banking system is determined not from the point of view of its external manifestation and perception, but from the point of view of its deep essence. Accordingly, the article focuses on the use of the method of deduction, not induction. As a result of the study, it was concluded that it was necessary to bring the current structure of the national banking system into conformity with the type of modern monetary system that has a market character. In practice, this correspondence can be achieved through such a qualitative transformation of the banking system, as a result of which it will become national in essence, private in content, state in form.

\section{Introduction}

In most modern economic publications, there is almost no question of a qualitative transformation of the banking system. More common are arguments about increasing the sustainability of this system $[1,2,3]$, about increasing the efficiency of its operation in terms of profitability [4, 5], etc. After analyzing the current state of affairs in the Russian banking system, the authors usually suggest, that: a) they should either choose commercial banks for more optimal lending directions, focusing, for example, on providing loans to small and medium-sized businesses $[6,7,8]$; b) or focus on improving the competence of management, the level of professionalism of bank employees, on strengthening internal control $[9,10]$; c) or recommend focusing on the stimulating nature of the regulatory activity of the Bank of Russia $[11,12]$. Each of these areas and specific measures to increase the efficiency of the functioning of the national banking system, of course, to a certain extent, has its own known relevance. However, in the opinion of the Russian school of economic thought, they are nevertheless superficial in nature and at the same time they partly resemble proposals made during the period of the functioning of the socialist economic system. At that time, various ways were proposed to improve the efficiency of this system, for 
example, by setting any new performance indicators to socialist enterprises, improving the quality of planning, etc. And only a few in those days dared to express the opinion that all these measures cannot lead to the desired result, since they are superficial in nature, whereas the system needs a fundamental transformation [13].

The same is now approved by the Russian school regarding the national banking system. Whatever private measures are proposed and applied to increase the efficiency of this system, they cannot provide the necessary result. They can only slow down its final degradation for a while. To get out of this situation, it is the radical transformation of the national banking system that is needed. In order to implement it practically, it is necessary first of all to comprehend a number of theoretical aspects of the real essence of both a separate bank and the banking system as a whole.

None of the Western schools of economic thought asks such a question. Marginalism, Keynesianism, monetarism, etc. are distinguished by their utility, pragmatism in the consideration of certain market phenomena and processes, but not by the desire to penetrate into their deepest essence. This distinguishes the Russian school of economic thought. And because of this, it declares the need for a qualitative transformation of the national banking system, partly similar to the one that happened with the socialist economic system. The main difference between the Russian school and the listed Western schools in terms of identifying the nature of the banking system is that it positions this system not only closely related to the monetary system of the country, but as part of this system.

\section{Statement of the Problem of Research}

The national monetary system is a system of a wider (holistic) order in relation to the banking system. The latter is part of the first; the part and the whole must be in organic conformity with each other. In fact, there was no such correspondence after the decisions made at the Jamaica International Monetary Conference (1976). As known, its decisions radically changed the monetary system. If during the whole previous period of development of market relations it was of a production type, now it became known as the neoliberal school of fiduciary economic thought, and banks were defined as credit organizations. At the same time, the banking and monetary systems began to be positioned simply as closely interconnected with each other, and not correlated as part and whole. The Russian School of Economic Thought considers such allegations to be groundless and actually biased.

The definition of a bank only as a credit institution, i.e. determination of the essence of a bank through focusing attention only on one of its functions is not reasonable. Of course, every bank is engaged in lending. However, this is not limited to its functions. Before acting as a creditor, the bank acts as a borrower. First, it forms its liabilities, attracting borrowed funds, and then it carries out active operations. At the same time, it is absolutely necessary to say that not only banks are engaged in borrowing and lending. This is done by many other participants in market relations (legal entities and individuals). And therefore, it cannot be argued that the provision of loans and attraction of loans is characteristic exclusively for banks. So the definition of banks as credit institutions is unreasonable.

The most immanent function of banks is to conduct settlements between their clients, between counterparties of market relations. This function is not performed by any other participant in market relations. And therefore, if we already establish the essence of a bank through the indication of its most inherent function, then it should be defined as a settlement institution. It should also be noted that a modern bank performs not only the three specified functions, but also many others, the number of which reaches up to a hundred. If we list all bank's functions when defining one, we get such a long complex word that will be unpredictable for everyday use. But even if such a word 
could have been used, it would have still not reflected the essence of the bank. The essence is the quintessence of the thing, what is contained in itself, while the function of a thing is something external to it. The function of a thing is its purpose. The essence and functions, of course, are ontologically related, but not identical. And therefore, through a simple enumeration of functions, it is impossible to establish the essence of a thing. This dialectical remark fully applies to banks. Their essence is not reduced to the functions they perform. It can be identified through appropriate analysis and in the historical context.

\section{Historical Context of Identification of the Essence}

\subsection{Bank and Banking System}

From the standpoint of the Russian school of economic thought, banks at the beginning of their activities were essentially functioning units of the market. And as such, they were part of the country's monetary system. They deposited coins first, then monetary gold, and first issued receipts (bills of exchange) to the amount of gold they had, and then issued notes in accordance with the scale of the monetary unit that existed at that time. The number of monetary units indicated on banknotes acted as a representative of a certain weight of gold held by the issuer of banknotes. Banknotes were in circulation, and monetary gold remained in the form of a treasure proper (qualitative certainty of money) in bank vaults. The appearance of an additional number of monetary units on the market (quantitative certainty of money), that is, an additional issue should have been preceded by an increase in the weight of gold (of a certain quality) in banks' vaults. Accordingly, banks in such conditions acted not only as cumulative functioning, but also self-rising units of the market, which as such were essentially opposed to the rest of the market, or, more precisely, to the goods offered for sale in the market. In such conditions, the banks did not have any liabilities, since it was not logical to borrow their banknotes from customers, and they did not operate with banknotes of other banks. Liabilities of the banks appeared only from the moment of the formation of the institute of the central bank, which began to issue banknotes of a single sample throughout the country.

With the advent of the Central Bank and the delegation of the emission function to it, banks turned from self-growing total functioning monetary units of the market into essentially functioning banknotes, which indicated a certain number of monetary units. One or another number of monetary units was designated not only on banknotes issued by the Central Bank, but also on bank accounts. And just as banknotes were one of the elements of the country's monetary system, so banks began to be essentially a part of this system.

\section{Modern Controversial Nature of Commercial Banks and Its Overcoming from the Position of Russian School of Economic Thought}

At the same time, it should be noted that since the formation of the Central Bank, the emergence of single banknotes and borrowed funds (liabilities) from banks, the latter began to play the role of financial intermediaries, conducting passive-active operations, seeking to self-increase not by replenishing their gold reserves, but through profit. And as such units, they were part of the national economy order. Thus, on the one hand, they initially constituted the affiliation of the country's monetary system, and on the other hand, they were almost part of the national economy. Within the framework of one system, they had one entity, and within the framework of another system they had another. So, making up part of the country's monetary system, they, again, were actually functioning banknotes and therefore could not compete with each other and strive to make a profit, and as part of the national economy, they were ordinary commercial companies competing with 
each other and seeking to make a profit. This internal inconsistency in the positioning of the banks was not overcome by the decisions of the Jamaican monetary conference. The decisions of this conference meant, first of all, that the funds are no longer the obligation of the Central Bank and, accordingly, they are not the requirements of the Central Bank for their conversion into gold. However, the removal of gold from the elements of the monetary system meant that not only commercial banks, but also the Central Bank began to be a functioning banknote. Thus, the entire set of banks has become essentially a set of functioning banknotes, which constitutes the institutional element of the country's monetary system.

As a result of this positioning of banks, a number of questions arise. If under the conditions of the modern monetary system they have essentially transformed into functioning banknotes, can they compete with each other? This question is identical to the question of whether one hundred and five hundred ruble bills can compete with each other, for example, can bills and electronic carriers compete with the number of monetary units? Obviously they can not. They complement each other, forming parts of a single holistic system. This raises another question: is the private ownership of banks justified? This question is identical to the question of whether privately-owned banknotes are justified. From the position of the Russian school - they are not. Just as banknotes and electronic carriers of the number of monetary units are in common use and constitute a common market identity, are part of the monetary system of a country, so banks must be in common use and constitute a common market identity, be part of the monetary system of a country. The monetary system of the country must be under the authority of the state, because the monetary function is a completely immanent function of the state from the very first moment of its existence.

When positioning a bank as a functioning banknote, it should also be noted that the purpose of the market (country) is not to increase the number of banknotes and not to increase the number of monetary units designated for them, but to increase money, i.e. the number of monetary units representing the increasing volume of the material content of the market in all the diversity of its forms. Composing part of the country's monetary system, rather than the national economy, the goal of banks should not be to earn their own profit, but to provide conditions for creating a national gross income [14]. With such a positioning of banks, their internal contradictions will be overcome.

By the way, the state-owned national banking system, in principle, cannot but be private in content. The content of the banking system is the number of funds placed on the accounts of individuals - bank customers.

\section{Some Benefits of Overcoming}

\subsection{Dualism in the Nature of Banks}

Since the banking system, which is under the authority of the state, cannot in principle go bankrupt, the trust in it from customers will be almost undoubted, which will condition the placement of temporarily idle funds in accounts for a long time. The availability of such funds in the banking system will provide an opportunity to provide loans for long periods, which in turn will have a positive impact on the investment activity of participants in market relations. This activity will increase not only due to the abolition of the desire of banks to make a profit, but also due to the abolition of the Central Bank rate. Lending activities of banks will have not a commercial, but a national focus. That is why the banking system will be not only state-shaped and private in content, but also national in essence. And this is the actual transformation of the national banking system, which is supported by the Russian school of economic thought in the framework of the modern monetary system, which is in fact not a fiduciary, but a market one. 


\section{Conclusion}

Thus, the common thing in the fundamental transformation of the socialist economic system and the modern banking system is the question of ownership. Only if under socialism this issue should have been decided in favor of privatization, that is, in favor of private property, now, on the contrary, it should be decided in favor of nationalization, or rather in favor of the state ownership of the banking system. The opposite of these fundamental transformations is their difference. One transformation has already occurred, now another is relevant. However, both the political leadership of the country did not want to hear about the first transformation at that time, so not only co-owners of central and commercial banks, but also various schools of Western economic thought do not want to hear about the second transformation, because their aspirations are aimed at solving the immediate problems that arise in the functioning of the banking system.

\section{References}

[1] Olejnikova I.N. Obespechenie ustojchivosti bankovskogo sektora v sisteme mehanizmov bankovskogo regulirovanija i nadzora Vestnik Taganrogskogo instituta upravlenija i jekonomiki. 2014. № 2 (20): 3-10 (In Russ.)

[2] Zham'janova A.B., Jakovleva I.A. Ustojchivost' bankovskogo sektora i ego obespechenie v sisteme mehanizmov bankovskogo regulirovanija $\mathrm{i}$ nadzora $\mathrm{V}$ sbornike: Bajkal'skie jekonomicheskie chtenija. Social'no-jekonomicheskoe razvitie regionov: problemy i perspektivy. Materialy mezhdunarodnoj nauchno-prakticheskoj konferencii. 2016: 160-163. (In Russ.)

[3] Kallaur P.V. Sistema obespechenija ustojchivosti bankovskogo sektora Respubliki Belarus'. Zh. Den'gi i kredit. 2008. № 6: 23-30. (In Russ.)

[4] Serebryakova O. A. Napravleniya povysheniya ehffektivnosti funktsionirovaniya bankovskogo sektora. SHkola universitetskoj nauki: paradigma razvitiya. 2010. Vol. 2. № 1 (1): 111-116. (In Russ.)

[5] Dijanskij A.V. Puti povyshenija jeffektivnosti bankovskogo sektora rossijskoj jekonomiki. Dissertacija na soiskanie uchenoj stepeni kandidata jekonomicheskih nauk / Moskva, 2000. $187 \mathrm{~s}$. (In Russ.)

[6] Koval'chuk N.B., Kovylova A.A. Opyt liderov bankovskogo rynka v kreditovanii malogo, srednego i krupnogo biznesa. V sbornike: Finansirovanie i kreditovanie rossijskogo biznesa: regional'nyj opyt, problemy, perspektivy 2016: 39-41. (In Russ.)

[7] Bocharova O.N., Potokina S.A., Lanina O.I. Analiz kreditovanija sub\#ektov malogo i srednego biznesa v Rossii: mery sozdanija blagoprijatnyh uslovij. Social'no-jekonomicheskie javlenija i processy. 2014. № 3 (61): 9-13.

[8] Elkin S.E., Elkina O.S., Tubanova Ju.B. Problemy kreditovanija malogo biznesa v Rossii SanktPeterburg. 2018. 304 s. (In Russ.)

[9] Krjachkova L.I., Mohov I.A., Mohova S.S. Institucional'nye problemy vnedrenija mehanizmov samoregulirovanija v bankovskij sektor RF Vestnik Kurskoj gosudarstvennoj sel'skohozjajstvennoj akademii. 2013. № 6: 18-20. (In Russ.)

[10] Tul'cova I.V. Osobennosti soderzhanija i organizacii truda $\mathrm{v}$ kommercheskom banke (po materialam kommercheskih bankov Jaroslavskoj oblasti). Vestnik Moskovskogo finansovojuridicheskogo universiteta. 2011. № 4: 138-146. (In Russ.)

[11] Mahmadov N.R. Napravlenija optimizacii dejatel'nosti Banka Rossii Jekonomika i predprinimatel'stvo. 2017. № 12-3 (89): 682-687. (In Russ.)

[12] Neronova-Makarova E.S. Bank Rossii: koncentracija nadzornyh funkcij $\mathrm{v}$ rukah mega reguljatora Jekonomika i socium. 2017. № 8 (39): 481-487. (In Russ.) 
[13] Kropin Ju.A. Vlast' hozjaina ili proizvol apparata? zh. Voprosy jekonomiki. 1989. №12: 101103. (In Russ.)

[14] Kropin Ju.A. Podderzhka delovoj aktivnosti i fundamental'naja problema reformirovanija nacional'noj bankovskoj sistemy zh. Jekonomika. Nalogi. Pravo. 2018. №3: 20-26. (In Russ.) 